\title{
Erratum
}

\section{Mediating meanings: conservation of the Staffordshire Hoard}

\section{Brian Castriota}

History of Art, University of Glasgow, Glasgow, UK.

postmedieval: a journal of medieval cultural studies (2017). 8, 134-135. doi:10.1057/s41280-017-0040-8

Correction to: postmedieval: a journal of medieval cultural studies 7, 369-377 (2016). doi: 10.1057/s41280-016-0003-5

We regret that an incorrect reference year was originally used in this article. The original article stated the following reference in the reference list:

Phillips, J. 2007. Reporting Iterations: A Documentation Model for Time-Based Media Art. In Revista de História da Arte 4: 168-179

The correct reference is:

Phillips, J. 2015. Reporting Iterations: A Documentation Model for Time-Based Media Art. In Revista de História da Arte 4: 168-179

A citation using the incorrect reference year was also used on p. 376 of the article, in footnote number 3, stating that 'Recent conservation literature has focused on the shifting identities of allographic works of modern and contemporary art (Laurenson, 2006; Phillips, 2007)...'. The sentence should have read 'Recent conservation literature has focused on the shifting identities of 
allographic works of modern and contemporary art (Laurenson, 2006; Phillips, 2015)...' The remainder of the research has not been affected and no other element of the article is under question. 